\title{
Belgeo
}

Revue belge de géographie

\section{Go west : internal migration in Germany after reunification}

Go West : interregionale Migration in Deutschland nach der Wiedervereinigung

\section{Birgit Glorius}

\section{(2) OpenEdition}

\section{Journals}

\section{Electronic version}

URL: http://journals.openedition.org/belgeo/6470

DOI: 10.4000/belgeo.6470

ISSN: 2294-9135

\section{Publisher:}

National Committee of Geography of Belgium, Société Royale Belge de Géographie

\section{Printed version}

Date of publication: 1 October 2010

Number of pages: 281-292

ISSN: 1377-2368

\section{Electronic reference}

Birgit Glorius, "Go west : internal migration in Germany after reunification », Belgeo [Online], 3 | 2010, Online since 15 December 2012, connection on 19 April 2019. URL : http://journals.openedition.org/ belgeo/6470 ; DOI : 10.4000/belgeo.6470

This text was automatically generated on 19 April 2019

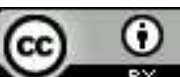

Belgeo est mis à disposition selon les termes de la licence Creative Commons Attribution 4.0 International. 


\title{
Go west : internal migration in Germany after reunification
}

Go West : interregionale Migration in Deutschland nach der Wiedervereinigung

\author{
Birgit Glorius
}

\section{Introduction}

1 Twenty years after German reunification, there are still tremendous socio-economic disparities between East and West German regions. Large parts of Eastern Germany appear as economically disadvantaged, with high unemployment rates and high shares of its population living on social transfers. Twenty years of selective outmigration with regards to age, gender and qualification as well as a sharp decrease of births in the first transformation years raised fears that East Germany will remain the poorer, older and less innovative part of Germany. This assessment is fed by several empirical studies (e.g. Dienel, 2005 ; Berlin Institut, 2007) and is largely accepted in public debate. However, the striking mainstream of results often hinders a critical evaluation of results from a regionally differentiated perspective. Therefore, this paper wants to address German internal east-west migration from a methodological perspective in order to determine the value of dedicated geographical approaches towards the thematic. It will do this by addressing the following topics : 1) the assessment of east-west-migration with regards to quantity and direction of flows, 2) the quality of flows, especially concerning human capital loss (brain drain), and 3) the probability and selectivity of remigration.

The paper is organized into five sections: Following the introductory part, theoretical approaches and methodological concepts concerning mobility processes and human capital flows will be reviewed. The third section presents methodology and implementation of a micro-study on east-west migration, whereof main results will be presented in section four. Section five discusses those results in the light of theory and methodology and draws a number of general conclusions towards the study of migratory processes. Original data for this paper stems from a research project on migration of 
young adults from the East German federal state Sachsen-Anhalt to West Germany, which was carried out at the Geographical Department of the Martin-Luther-University HalleWittenberg during the years 2003-2007².

\section{East-West-Migration in Germany : Patterns and Determinants}

3 East Germany is shrinking: Since the fall of the Berlin Wall until 2006, the net loss due to (mainly internal) migration amounted to 1.74 million people - almost one tenth of the former GDR's population. Quite often, in public debate this significant outflow of population is perceived as extraordinary and mobility as such is interpreted as a negative signal for the future development of East Germany. However, a certain degree of mobility is not unusual in modern societies, especially for persons of younger age or with higher qualifications. On the national comparative level, East Germany rather appears as a region with mobility below average : in 2006, there were 34.9 moves per 1,000 inhabitants in the East, while in the West 45.3 moves per 1,000 inhabitants were recorded (StBA, 2007). Hence, it is not the higher aptness towards mobility, but rather the missing counterstream that evokes the East German "migration problem" (Wiest, Kubis and Schneider, 2009, p. 372).

Between 2001 and 2006, three million departures to West Germany were paralleled by about two million moves in the opposite direction. A considerable part of this counterflow consists of returning migrants. An analysis of panel data from the German socio-economic panel (SOEP) suggests the share of returnees in the counterflow as of $50 \%$; altogether, about $20 \%$ of those persons who left East Germany between 1991 and 2000 returned until 2001, thus constituting a high circular component in the internal migration process (Beck, 2004, p. 106).

5 Evidently, migration numbers and rates are not evenly spread over the age groups (Figure 1) : the largest number of departures was produced by persons aged 30 to 49 years. The departure of this population at family age, together with their children (age group 0 to 17), was especially characteristic for the first transformation period until 1993, when the economic breakdown and a massive loss of jobs forced numerous families to look for new opportunities in West Germany (Friedrich, 2008, p. 15). Their interregional mobility decreased after 1993, while the governmental move from Bonn to Berlin and the restructuring of public administration induced a high eastward flow of young professionals and civil servants with their families, thus largely equalizing the departures in the age groups 25-29 and in the family age groups (30-49, and 0-17). Economic crisis towards the end of the 1990s again fuelled east-west mobility, now mainly affecting the age groups of young adults (18-24), who always had a considerable share in the outflows during the observation period. This age group, mainly at higher education age or in the beginning of their professional career, has the highest negative migration balance $(-44 \%$ ), and also adds to over one third ( $36 \%$ ) of the total net population loss within the period 1991 to 2006. 
Figure 1. Internal Migration Balance of East-West-Migration in Germany, 2001 - 2006.

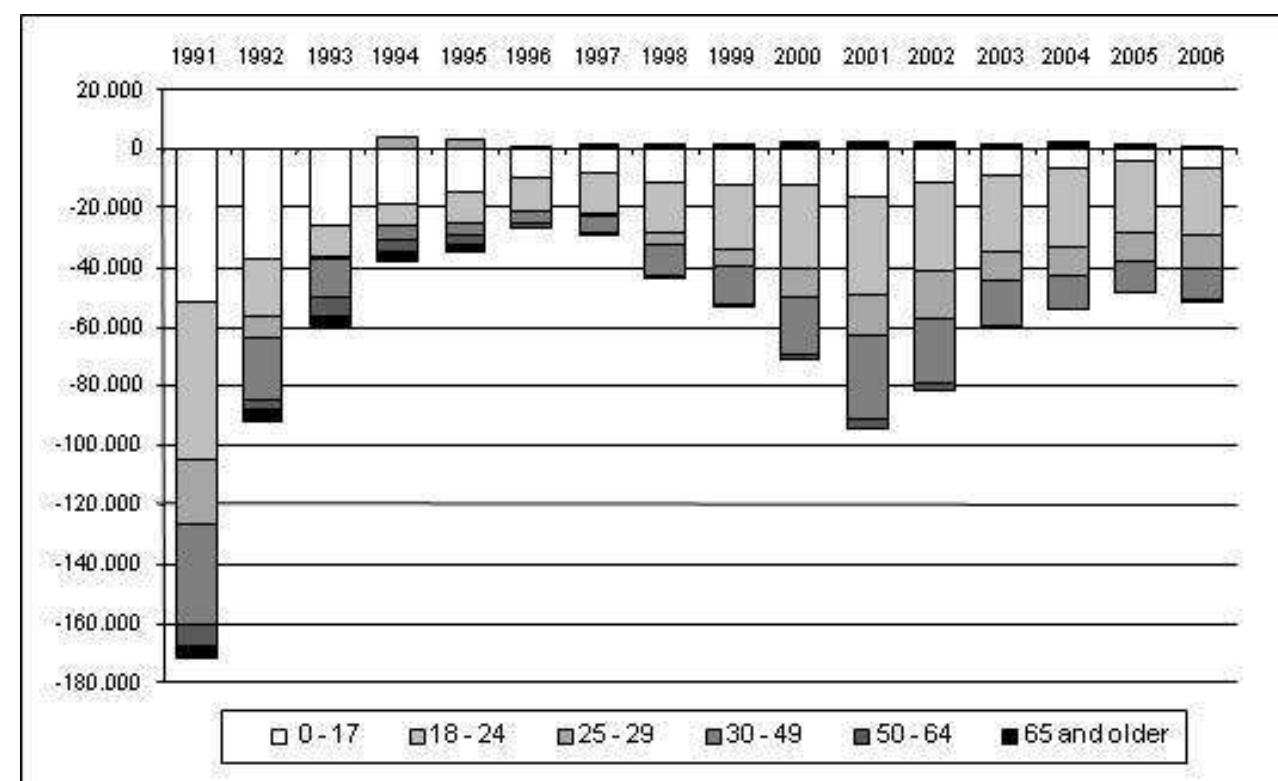

SOURCE : FRIEDRICH 2008 : 15, DATA SOURCE : STATISTICAL OFfICE OF THE FRG

6 Also noticeable is the high gender selectivity in the internal migration streams : While in the years 1991 to $2006,50.5 \%$ of east-west-migrants were female, their share was only $45.0 \%$ in the counterflow. This imbalance is even more obvious in the age group 18 to 30 years, with a female share of $52.9 \%$ in the outflow against $47.2 \%$ in the counterflow. Broken down in total numbers, the negative net migration balance of women sums up to 630,000 , while for men a net balance of - 400,000 can be reported (Schultz, 2009, p. 56). This inequality of migratory moves culminated to significant changes in the gender proportion, which reaches disproportions of $15-20 \%$ in the age group 18-29 in some (mostly peripheral) regions of East Germany (Berlin Institut, 2007, p. 41).

7 However, the biggest concern regarding east-west-migration is the problem of human capital loss. The migratory movements are highly selective with regards to education and formal qualification: Kempe (2001) and Schneider (2005) used SOEP data to determine the human capital loss. They found that outmigrants of the years 1999-2003 were positively selected with regards to education, with $32 \%$ holding a university entrance certificate (Abitur or Fachabitur), while this share was only $18 \%$ in the East Germany population. Regarding tertiary education, positive selectivity was less obvious, with higher vocational or academic qualifications even being underrepresented in the outflow. But Schneider (2005, pp. 309f) correctly points out, that the high participation of young adults with high educational degrees but without vocational or academic degrees in the outflow means, that east-west migration is mainly driven by educational goals or in search for the first labour market entry. This finding is also supported by Sunder, Trocka and Günther (2008, p.375), who compare university data regarding regional selectivity of first-degree students and graduates. They find high negative migration balances especially in the case of first degree students for most of the East German federal states, for example minus $19 \%$ for Sachsen-Anhalt in the winter-terms 2005/06 through 2007/08. But also for vocational training, where facilities usually are allocated more evenly over the regions, there can be considered a push-effect (Kubis and Schneider, 2007, p. 13). Thus, as a main 
motive of internal migration, labour market effects as well as educational demands can be hypothesized as important components.

\section{Theoretical Approaches from international migration research}

Generally, explanatory approaches towards migratory movements are mainly focusing on labour migration, thus concentrating mostly on economic migration theories but also integrate behavioural approaches. A second body of theories discussed in this section concerns the human capital aspect of migration, that is questions of brain drain, brain gain and brain circulation. Even though the theoretical design of most of the theories discussed is directed to an international comparative level of observation, explanatory power can also be drawn for interregional mobility processes, especially if - like in the case of re-united Germany - high regional disparities in terms of wages and living conditions exist. Taking up the seminal debate on methodological nationalism in migration studies, it is also worth translating concepts of transnationalism on an intranational scale.

\section{The economic and geographical perspective in international migration research}

One important group of theoretical approaches addresses structural components in source and destination countries on a macro level in order to explain the quantity and direction of migratory flows. As mobility was always found to be connected with societal development, this aspect was already considered within the very first theoretical approaches, like for example Ravenstein's (1885/89) laws of migration, considering the effects of industrial revolution and urbanisation processes as explanatory variables. Also Zelinsky's (1971) model of mobility transition draws connections between social and geographical mobility in the context of societal modernisation processes. Lee (1966) refined Ravenstein's theory by introducing a classification of push- and pull factors driving the migration decision and direction. Harris and Todaro (1970) analyze labour migration in the context of economic development; they explain international and internal migration through the regional differential of wages and work opportunities and assume that the migratory flow is directed towards regions or countries with higher wage level.

Micro-theories, on the other hand, are focusing on the individual migration decisions, stressing behavioural aspects of individual actors, but also their embeddedness in social systems, which both might shape migratory decisions. Sjaastad's (1962) human capital theory considers individual migration decisions as a result of mainly cost-benefit calculations. The expected gains from a move are the net difference between the expected wages in the country of arrival, the lower wages in the country of origin and the costs of migration. Those costs also include non-monetary costs, like the loss of former social networks and the need to adapt to a new social environment.

11 Methodologically, most of the above-mentioned econometric theories are aiming on a mathematical modelling of migratory processes via statistical regression. However, model variables proved to be difficult to capture, so that a falsification is difficult (Haug, 2000, p. 33). Furthermore, their explanatory value was found to decrease for modern societies 
which are characterized by high welfare levels (thus obviating economic pressure as migratory push-factor) and changing societal features such as reduced social control coupled with increasing individual autonomy and market orientation, as described in the theory of second demographic transition (Lesthaeghe, 1992).

The growing critique at solely econometric migration models fell together with a general re-orientation in human geography, entailing a number of paradigmatic changes and a re-conceptualisation of important spatial and social categories (White and Jackson, 1995, p.111). For geographical mobility research this meant a new understanding of international migration as sequences within an individuals' mobility biography, remaining open with regards to duration and ultimateness of stay, rather than migration as unidirectional and definite event (Glorius, 2007, pp. 25f). Today, the importance and relevance of social networks is considered when studying migratory processes (Faist, 1997). While social networks at the place of arrival can reduce costs and risks of migration and thus increase the probability of mobility, social ties at the place of origin might rather prevent migratory moves or raise the probability for return migration. Modern transport and communication systems considerably facilitated possibilities for migrants to keep dense and emotionally deep contacts, thus creating new social spheres of reference which are located beyond national boundaries and are therefore addressed as transnational social spaces (Pries, 1996). This new perspective has significant consequences for geographical migration research, as it seems to imply the crucial need for micro-level approaches, integrating behavioural factors, network activities and the question of migrant identity and belonging (McHugh, 2000, p. 72). Regarding research methodology, those conceptualizations imply the extension of the empirical research field along those lines transnational social fields are setting in geographical space: beyond national boundaries, connecting society of origin and society of arrival.

Another important re-conceptualisation of research categories stems from the debate on methodological nationalism, which demonstrates "that nation-state building processes have fundamentally shaped the ways immigration has been perceived and received" (Wimmer and Glick-Schiller, 2002, p. 301). Methodological nationalism is existing in three modes : 1) the taking-for-granted of national discourses and histories of naturalization and of territorial limitations, thus ignoring how those discourses influence the object of research, 2) the naturalization of the nation state, thus hypothesizing cultural homogeneity of a people and concentrating on the otherness of immigrants in research, and 3) "the territorialization of social science imaginary and the reduction of the analytical focus to the boundaries of the nation-state" (Wimmer and Glick-Schiller, 2002, p. 307). Translating those arguments to an intra-national scale could be a fruitful attempt to deconstruct research settings that are based on the hypothesis of otherness - usually implying inferiority - of regions within national boundaries, such as East Germany or the Italian Mezzogiorno.

\section{Migration and human capital transfer in a regional perspective}

Modern societies increasingly draw attention on the availability and utilization of human capital, as it is perceived to be crucial for the development of knowledge based economies. There is a growing body of research dealing with the nexus of migration and development, especially focusing on mobility of the highly skilled ${ }^{2}$. Explanatory designs mostly consider human capital theory and Bourdieu's theoretical body on cultural capital 
(Bourdieu, 1986). Initially studies were focusing on the loss of human capital due to emigration and the negative impacts for less developed source countries. More recent studies consider the possibility of brain return and study the impact of return migrants on the economic development of their source countries. Those studies - mostly addressing examples of Asian countries - suggest that a brain drain situation can change into a brain gain if migrants return with additional qualifications, knowledge and capital and bring innovative input back to their home country (Hunger, 2000 ; Saxenian and Hsu, 2001).

15 While brain mobility appears to be well researched on an international scale, human capital flows within nation states seem to lag behind. This is quite surprising, as the problematic of selective rural-urban-migration was discovered very early in history (Meusburger, 1998, p.384). Among the rare regional studies which consider human capital aspects is the piece of Flüchter (1990), who analyzed the mobility of Japanese university graduates and found significant differences in return quota (between $78.5 \%$ in Tokyo region and $25.7 \%$ in the peripheral Saga region) which were clearly connected to geographical attributes of the source region such as centrality or agglomeration factor. In her study on the regional selectivity of returning Polish academics Klein-Hitpass (2011) found, that returnees rather tend to choose established centres of economic and political power than less advanced - but maybe more dynamic - agglomerations. Also Jahnke (2005), who analyzed the interregional mobility of Italian university graduates with special focus on the Italian Mezzogiorno found, that rather the less excellent graduates returned to this peripheral region, thus limiting the positive impact of brain return. Therefore, from a regionally differentiating perspective, migration as well as remigration seems to deepen the divide between urban agglomerations and rural peripheries within a country.

\section{Methodology and Implementation}

Based on the above elaborated theoretical considerations and empirical findings, our own case study on young migrating adults from Sachsen-Anhalt aimed to 1) deliver a detailed assessment of the regional structure of migratory flows, 2) analyse the internal migration under human capital aspects and 3) consider the probability and selectivity of return migration.

In our research design, we followed a multi-level approach, combining quantitative and qualitative empirical methods as well as the analysis of secondary data ${ }^{3}$. In a detailed telephone based survey, we collected data on migration biography, migration motive, living circumstances and social integration before and after the move, return intentions and socio-demographic variables. The addressees for our survey were defined as those migrants, who left the federal state of Sachsen-Anhalt between 1998 and 2002 at ages 18 to 35. As registration and deregistration data are recorded locally, we drew a cluster sample of 24 municipalities out of a total of 224, making sure that all existing categories of community size and structure were included, and gathered a total of 15,421 addresses, of which about $15 \%$ could be matched with a valid telephone number. During the CATIsurvey, 1,161 valid answer files were produced. The data were imported into the analytical software SPSS and underwent descriptive and multivariate analysis (factorial and cluster analysis). In order to obtain an integrative view on the mobility decisions, the integration process and return probability, ten focused interviews were carried out with 
young migrants who were found by specific calls and by snowball-method. Expert interviews and the analysis of secondary data completed the research design.

The quantitative sample ${ }^{4}$ reached an almost even gender breakdown, the age breakdown was equivalent to migration statistics in the relevant years. The migratory move was largely correlated to biographical changes such as graduating from secondary school or completing tertiary education: $12 \%$ of interviewees moved within one year after graduating from school, and $25 \%$ moved within one year after completing tertiary education, thus underlining the main migratory motive as being labour market induced.

Main migratory motives were economic or labour market factors in source and destination region, with economic push-factors largely augmenting pull-factors : factorial analysis of several open and closed questions regarding migration motivation revealed that $40 \%$ of our interviewees moved mainly because of precarious living circumstances at home, such as unemployment ( $38 \%$ were unemployed prior to migration) or the fear of unemployment or generally poor future perspectives, while $20 \%$ were seeking for career advancement and $7 \%$ primarily expected better income opportunities. A large group of migrants ( $28 \%$, of which two thirds women) moved mainly for the purpose of family reunification. Noticeable in the context of new mobility paradigms discussed above is the fact that $43 \%$ of our interviewees were secondary migrants, meaning that they were not born in Sachsen-Anhalt. Of those, a considerable part (44\%) was born abroad ${ }^{5}$, while the others either originated from West Germany (35\%) or from other parts of East Germany (21\%). This underlines the fact, that German east-west migration has a high circular component and is furthermore embedded in the European and global migratory space.

\section{Presentation of Selected Results}

In the following section, we will present central results concerning 1) the assessment of east-west-migration with regards to quantity and direction of flows, 2) the quality of flows, especially with regards to human capital loss (brain drain), and 3) the probability of remigration and its measurement.

\section{Geographical selectivity of destination choice}

21 According to our sample, mainly the agglomerations benefited from east-west migration. Nearly half of our interviewees settled in the largest West German agglomerations, while only every tenth move was directed towards a rural region (Schultz, 2009, pp. 58-95). Particularly the highly qualified were drawn to the large agglomerations, thereby covering greater distances than those migrants with lower qualifications. A decisive factor of destination choice was found in the social networks at the places of arrival. That is, especially young migrants (18-20) looking for vocational training largely relied on help and agency of friends or relatives who already had settled in the West German destination. Sometimes, those networks not only structured the destination choice, but also facilitated the migratory decision as such.

A considerable regional selectivity is not only found in the destination regions, but also concerning the source regions: The relatively largest outflows, especially of the young population we were focusing upon, rather concerned peripheral rural regions or old industrial regions with scarce educational or labour market possibilities, while large 
agglomerations in Eastern Germany and their surrounding territories are experiencing positive migration balances due to east-east- but also west-east-migration. A further regional type with regards to interregional mobility is identified along the former border between East and West Germany. In those border-regions, a high proportion of East German population is commuting to a West German workplace nearby, so that commuting may be a substitute for migration in those areas (Schultz, 2009, 61f).

\section{Quality of flows : a classification with regards to human capital loss}

Our interviewees were significantly better educated than their age peers in SachsenAnhalt, with $43 \%$ ( $25 \%$ in peer group) holding a university entrance certificate. At the time of the survey, the majority had completed tertiary education and was employed, either full time (66\%) or part-time (11\%) or self-employed (3\%); only $14 \%$ were not working, as they were on parental leave (3\%), undertook further training (3\%) or reported unemployment $(8 \%)$. Therefore, labour market integration can be assessed positively, and also income levels of migrants were considerably raised.

Roughly half of the interviewees were employed on a medium status position, often in health services $(14 \%)$ or administrative jobs $(17 \%)$. One quarter worked either in low occupational positions (metal workers, drivers, waiters, care takers, sales assistants) or in highly qualified jobs, such as engineers, scientists, physicians or managers. Thus, the qualification profile of our interviewees does not suggest a brain drain with regards to the established qualification criteria. However, in comparison to the source regions' labour market structure, especially high qualified and strongly demanded occupational groups such as technicians, engineers and professional services were strongly overrepresented among the interviewees, suggesting that source regions are indeed facing a considerable brain drain.

\section{Return : high significance of social networks}

As already mentioned, the east-west and west-east streams have a high circular component : in our sample, $15 \%$ of interviewees were returnees to West Germany, and panel data suggest a share of returnees in the eastward flows up to $50 \%$ (Schultz, 2009, p. 69 ; Beck, 2004, p. 106). For a correct evaluation of the movements under human capital aspects, the return probability and the human capital structure of potential remigrants is of high importance. In our survey, almost half of the interviewees ( $47 \%$ ) could imagine returning to Sachsen-Anhalt and further $17 \%$ would eventually return.

Following neoclassical theory, a negative selection with regards to labour market success must be hypothesised for remigrants, while social network theory suggests that intensive social contacts to the source region might fuel remigration decisions. We integrated those hypotheses into an ordered probit ${ }^{6}$ and found high significance of both factors concerning the readiness to return: Regarding labour market success, a disappointed person has a propensity of $63 \%$ for remigration plans, while a successful person has a propensity of $46 \%$. Also for the social network factor we found high correlations between intensity of contacts to the source region and return intention. Noticeable is, that leaving aside the high significances found for our model - a significant share of the successful and not homebound migrants also considered remigration. However, the economic situation in the home region is crucial for a return, as most interviewees take 
equal or even higher income levels than in their actual destination as a precondition for remigration.

\section{Discussion of Results and Conclusion}

Regional case studies which analyze regional specifics but also show generalizations of human behaviour in space can clearly enhance our knowledge about decisive factors of migratory movements. In this final section, we want to elaborate on some outcomes of our case study and shed light on the specific value of geographical (meaning regionally oriented and spatially embedded) approaches in migration research.

In our study, we found strong differences of migratory patterns for source and destination regions with regards to their position within the country (central/prospering - peripheral/stagnating) as well as - on a micro-regional level - with regards to their position in the agglomerative system. We found a high rural-urban component in migratory streams which created a pattern of winner and looser regions with regards to quantitative and qualitative demographic features. This systematic seems to be applicable also to other geographical or national entities.

However, we also observed patterns that seemingly would not fit into the general picture, such as the high migratory streams from Sachsen-Anhalt towards the economically less dynamic federal state of Niedersachsen, or a significant proportion of migrants who moved to rural areas. We found that geographical proximity went in line with social proximity, and that those patterns above all affected the younger and less well educated migrants seeking for vocational education or a medium qualified job. Those features could not be explained by solely economic or gravitation models, but rather needed the integration of social and demographic theory. This leads us to the general conclusion, that it is especially the exceptions and not the mainstream of results that make regional studies so valuable for understanding migratory patterns.

Regarding the human capital aspects of our empirical example, it was already elaborated that the usual brain drain definition seems inappropriate in absolute terms, as we only had a minority of highly qualified migrants. On the other hand we did register a loss of human capital in relative terms, as there was a higher proportion of migrants with high education levels and those working in high ranked labour market segments in relation to the source population. For a generalization of results, we suggest to refine the brain drain definition and not only consider academic degrees or occupational status but integrate the demand-supply patterns of regional labour markets. For each case study, the relevant variables for human capital loss should be chosen with regards to the regional specifics.

Distinct explanatory models to determine the propensity to return are useful to make a prognosis concerning selectivity of return, but are not able to display migratory realities. Longitudinal studies can help to explain return and to capture the connections between migratory moves, career development and family life cycle. The birth of a child, for example, significantly changes labour market integration and career development especially for women, and might also lead to a re-evaluation of social networks in source and destination region, thus influencing mobility decisions. Therefore, there seems to be a strong imperative to integrate demographic and gender approaches into migration studies. 

our sample, which partly thwarts the above made hypotheses and elaborations on brain drain effects and return propensity. The fact that this result was unexpected is due to the base hypothesis that human mobility is the exception to the rule of sedentariness, a hypothesis valid for mobility research in general, which is underlined by German mobility statistics calculating a lower mobility ratio for East Germany in comparison to West Germany. Deconstructing this base hypothesis according to the naturalization paradigm from methodological nationalism can bring another perspective into this case study: we were studying an inhomogeneous population according to their mobility biographies and aspirations, but neglected this difference by hypothesizing a homogeneous group on the common ground of the regional container of Sachsen-Anhalt. If we extend this notion to the German case in general, we could hypothesize that higher mobility levels of the West German population is due to their higher share of people with migration biographies - either migrants from abroad or second, third, and fourth generation of migrants, including the offspring of replaced Germans after the Second World War. Maybe a study of mobility and immobility biographies would further give valuable answers to key questions regarding intra-national mobility.

Thus, combining systematic regional knowledge with theoretically oriented research questions and interdisciplinary research approaches appears to be a challenging but promising task for modern geographical mobility research (Fassmann, 2002, pp. 345ff).

\section{BIBLIOGRAPHY}

BECK G. (2004), "Wandern gegen den Strom : West-Ost-Migration in Deutschland", in SWIACZNY F., HAUG S. (eds.), Bevölkerungsgeographische Forschung zur Migration und Integration. Materialien zur Bevölkerungswissenschaft, 112, pp. 95-112, Wiesbaden, Bundesinstitut für Bevölkerungsforschung.

BERLIN INSTITUT (ed.), authored by KRÖHNERT S. \& KLINGHOLZ R. (2007), Not am Mann. Vom Helden der Arbeit zur neuen Unterschicht? Lebenslagen junger Erwachsener in wirtschaftlichen Abstiegsregionen der neuen Bundesländer, Berlin, Berlin Institut für Bevölkerung und Entwicklung. BOURDIEU P. (1986), “The Forms of Capital”, in RICHARDSON J.G. (ed.), Handbook of Theory and Research for the Sociology of Education, New York, Greenwood Press, pp. 241-260.

BUNDESMINISTERIUM DES INNERN (ed.) (2008), Migrationsbericht 2007, Nürnberg, Bundesamt für Migration und Flüchtlinge.

DIENEL CH. (ed.) (2005), Abwanderung, Geburtenrückgang und regionale Entwicklung. Ursachen und Folgen des Bevölkerungsrückgangs in Ostdeutschland, Wiesbaden, VS Verlag für Sozialwissenschaften.

FAIST T. (1997), "Migration und der Transfer sozialen Kapitals oder : Warum gibt es relativ wenige internationale Migranten ?", in PRIES L. (ed.), Transnationale Migration (Soziale Welt, Sonderband, 12), Baden-Baden, Nomos, pp. 63-83. 
FASSMANN H. (2002), “Transnationale Mobilität : Empirische Befunde und theoretische Überlegungen”, Leviathan, Berliner Zeitschrift für Sozialwissenschaft, 3, Wiesbaden, VS Verlag für Sozialwissenschaften, pp. 345-359.

FLÜCHTER W. (1990), "Hochschulstandorte und Bildungsverhalten unter Aspekten der Raumordnung in Japan”, Bochumer Geographische Arbeiten 52, Paderborn, Schöningh.

FRIEDRICH K. (2008), “16 Jahre innerdeutsche Ost-West-Migration - eine Einführung in die Transformation eines geschlossenen Migrationsregimes in die Postmoderne", in FRIEDRICH K. and SCHULTZ A. (eds.), Brain drain oder brain circulation? Konsequenzen und Perspektiven der OstWest-Migration, Forum IFL, 8, Leipzig, Institut für Länderkunde.

GAILLARD A. M. and GAILLARD J. (1998), International migration of the highly qualified : a bibliographic and conceptual itinerary, New York, Center for Migration Studies.

GLORIUS B. (2007), Transnationale Perspektiven. Eine Studie zur Migration zwischen Polen und Deutschland, Bielefeld, transcript.

HARRIS J.R. and TODARO M. (1970), "Migration, unemployment and development : a two-sector analysis", American Economic Review, 60, Nashville, American Economic Association, pp. 126-142.

HAUG S. (2000), Soziales Kapital und Kettenmigration. Italienische Migranten in Deutschland, Opladen, Leske \& Budrich.

HUNGER U. (2000), “Vom Brain Drain zum Brain Gain : Migration, Netzwerkbildung und sozioökonomische Entwicklung : das Beispiel der indischen Software-Migranten”, IMIS-Beiträge, 16, pp. 7-21, Osnabrück, Institut für Migrationsforschung und interkulturelle Studien.

JAHNKE H. (2005), “Der italienische Mezzogoirno auf dem Weg in die europäische Wissensgesellschaft. Eine Untersuchung der Erwerbssituation und der regionalen Mobilität junger Akademiker am Beispiel Siziliens", Berliner Geographische Arbeiten, 101, Berlin, Geogra phisches Institut der Humboldt Universität zu Berlin.

KEMPE W. (2001), “Neuer Trend in der Bildungsstruktur der Ost-West-Wanderung ?”, Wirtschaft im Wandel, 9, Halle, Halle Institute for Economic Research, pp. 205-210.

KLEIN-HITPASS (2011), "Regional selectivity of return migration - the locational choice of highskilled return migrants in Poland”, in GLORIUS B., GRABOWSKA-LUSINSKA I. and KUVIK A. (eds.), Mobility in Transition : migration patterns after EU enlargement, Amsterdam, Amsterdam University Press (in preparation).

KUBIS A. and SCHEIDER L. (2007), "Determinants of Female Migration - The Case of German NUTS 3 Regions", IWH-Discussion Papers 12, Halle, Halle Institute for Economic Research.

LEE E.S. (1966), “A Theory of Migration”, Demography, 3, 1, Baltimore, Johns Hopkins University Press, pp. 47-57.

LESTHAEGHE R. (1992), “Der zweite demographische Übergang in den westlichen Ländern : Eine Deutung”, Zeitschrift für Bevölkerungswissenschaften, 18, 3, Wiesbaden, VS Verlag für Sozialwissenschaften, pp. 313-354.

McHUGH K.E. (2000), "Inside, outside, upside down, backward, forward, round and round : a case for ethnographic studies in migration", Progress in Human Geography, 24, 1, London, Sage Publications, pp. 71-89.

MEUSBURGER P. (1998), Bildungsgeographie. Wissen und Ausbildung in der räumlichen Dimension, Heidelberg/Berlin, Spektrum Akademischer Verlag. 
PRIES L. (1996), “Transnationale Soziale Räume. Theoretisch-empirische Skizze am Beispiel der Arbeitswanderungen Mexico - USA”, Zeitschrift für Soziologie, 25, 6, Bielefeld, Fakultät für Soziologie, pp. 456-472.

RAVENSTEIN E.G. (1885/89), “The laws of migration”, Journal of the royal statistical society, 48, pp. 167-277 and 52, pp. 241-301, London, Blackwell Publishing.

SAXENIAN A.L. and HSU J.Y. (2001), "The Silicon Valley-Hsinchu Connection : Technical Communities and Industrial Upgrading", Industrial and Corporate Change, 10, 4, Oxford, Oxford University Press, pp. 893-920.

SCHNEIDER L. (2005), “Ost-West-Binnenwanderung : Gravierender Verlust an Humankapital”, Wirtschaft im Wandel, 10, Halle, Halle Institute for Economic Research, pp. 309-314.

SCHULTZ A. (2009), Brain drain aus Ostdeutschland? Ausmaß, Bestimmungsgründe und Folgen selektiver Abwanderung, Leipzig, Deutsche Akademie für Landeskunde.

SJAASTAD L. A. (1962), “The costs and return of human migration”, Journal of Political Economy, 70, Supplement, Chicago, University of Chicago Press, pp. 80-93.

StBA (STATISTISCHES BUNDESAMT) (ed.) (2007), Wanderungen ( = Fachserie 1, Reihe 1.2), Wiesbaden, Statistisches Bundesamt.

SUNDER M., TROCKA D. and GÜNTHER J. (2008), "Brain Gain und Brain Drain : HochschulBildungswanderung im föderalen Deutschland", Wirtschaft im Wandel, 10, Halle, Halle Institute for Economic Research, p. 375.

WHITE P. and JACKSON P. (1995), “(Re)theorising Population Geography”, International Journal of Population Geography, 1, Hoboken, NJ, John Wiley \& Sons, Ltd, pp. 111-123.

WIEST D., KUBIS A. and SCHEIDER L (2009), "Rückwanderung nach Ostdeutschland : Erfolg bremst Heimkehrneigung”, Wirtschaft im Wandel, 9, Halle, Halle Institute for Economic Research, pp. 372-379.

WIMMER A. and GLICK-SCHILLER N. (2002), "Methodological nationalism and beyond : nationstate building, migration and the social sciences", Global Networks, 2, 4, Oxford, Blackwell Publishing, pp. 301-334.

ZELINSKY W. (1971), “The hypothesis of the mobility transition”, Geographical Review, 61, 2, New York, American Geographical Society, pp. 219-249.

\section{NOTES}

1. The study "Brain Drain from East Germany » was financed by the German Research Fund DFG (Deutsche Forschungsgemeinschaft). Main researcher was Andrea Schultz, under the supervision of Klaus Friedrich, both from the Geographical Department of the MLU.

2. A systematic revue and evaluation of studies can be found in Gaillard and Gaillard (1998).

3. More details on the survey and the survey instruments can be found in Schultz (2009).

4. All primary results reported here are originally reported and elaborated in Schultz (2009).

5. This subgroup mainly consisted of ethnic german Spätaussiedler, who - upon arrival in Germany - are distributed among the German federal states in order to ensure equality concerning public integration costs. The assigned place of stay is obligatory for three years ; after this period, the Spätaussiedler are free to move internally, often chosing destinations where members of the extended family live (Bundesministerium des Innern, 2007, p. 50). 
6. This analytical step was undertaken in cooperation with Alexander Kubis and Lutz Schneider from Halle Institute for Economic Research. More details on model design and outcomes can be found in Wiest, Kubis and Schneider (2009).

\section{ABSTRACTS}

The paper wants to shed light on the phenomenon of internal migration in Germany after the fall of the iron curtain. Since German reunification, the eastern part of Germany lost a large share of its population due to internal migration. Whereas in the beginning, departures were spread evenly over all age and educational groups and were accompanied by a significant counterstream, in the course of time the negative migration balance was mainly produced by younger people at the beginning of their professional career. The paper describes the development of internal east-west migration in detail and presents primary data on the profiles of young migrants drawn from a research project during the years 2004-2007 (in this research project, financed by the German Research Foundation DFG, data were gathered from 1,200 migrants aged between 18-35 who moved from the federal state Sachsen-Anhalt to the western part of Germany). Hereby, special emphasis will be given to the methodological implications of studying selective migration processes. Final conclusions are drawn regarding the regional assessment and theoretical classification of this migration process, but also on the theoretical and methodological constraints of mobility research.

Seit der deutschen Wiedervereinigung hat Ostdeutschland beträchtliche Bevölkerungsverluste aufgrund von innerdeutschen Wanderungen zu verzeichnen. Während der Migrationsstrom zunächst relativ gleichmäßig über alle Bevölkerungsgruppen hinsichtlich Alter und Bildungsstand verteilt war und überdies von einem signifikanten Gegenstrom begleitet wurde, hat er sich im Laufe der $1990^{\mathrm{er}}$ Jahre ausdifferenziert. Die negative Wanderungsbilanz ist heute vor allem durch die Abwanderung junger Menschen $\mathrm{zu}$ Beginn des Erwerbslebens gekennzeichnet. Der Beitrag bietet eine detaillierte Beschreibung der innerdeutschen Ost-WestWanderung und präsentiert empirische Primärdaten zu den Profilen junger Ost-West-Migranten aus Sachsen-Anhalt (die Daten stammen aus einer durch die Deutsche Forschungsgemeinschaft DFG finanzierten Studie zur innerdeutschen Ost-West-Wanderung, die 1.200 junge Abwanderer zwischen 18 und 35 Jahren umfasste). Die abschließende Generalisierung gibt Hinweise bezüglich der spezifischen geographischen Kompetenzen - aber auch der Fallstricke - im Bereich der internationalen und intra-nationalen Migrationsforschung.

\section{INDEX}

Keywords: internal migration, brain drain, regional study, Germany

Schlüsselwörter: interregionale Migration, Regionalstudie, Deutschland 


\section{AUTHOR}

\section{BIRGIT GLORIUS}

Martin-Luther-University Halle/Germany, Department of Geoscience, Social Geography, D 06099 Halle (Saale), birgit.glorius@geo.uni-halle.de 